\title{
MODEL PENYUSUTAN MAJEMUK JUMLAH PESERTA ASURANSI PADA ASURANSI JIWA
}

\author{
WILLIAM HUDA, DODI DEVIANTO, YUDIANTRI ASDI \\ Program Studi Matematika, \\ Fakultas Matematika dan Ilmu Pengetahuan Alam, Universitas Andalas, \\ Kampus UNAND Limau Manis Padang, Indonesia, \\ wrepaiwank@yahoo.com
}

\begin{abstract}
Abstrak. Model penyusutan majemuk adalah model penyusutan dimana penyusutan jumlah polis tidak hanya disebabkan oleh satu sebab saja, misalkan kematian, namun mungkin juga disebabkan oleh cacat, maupun sebab-sebab yang lain. Dalam pembentukan tabel penyusutan majemuk, dapat dikaitkan dari tabel penyusutan tunggal yang telah diketahui. Jumlah pembayaran premi untuk asuransi jiwa bergantung pada jenis program asuransi yang telah diambil. Dalam tulisan ini diturunkan beberapa model dalam asuransi jiwa dengan intentitas kepentingan dalam menghadapi beberapa jenis penyusutan, yakni dengan menggunakan dua sebab penyusutan, yaitu kematian dan cacat.

Kata Kunci: penyusutan majemuk, polis, anuitas
\end{abstract}

\section{Pendahuluan}

Perkembangan industri asuransi selaras dengan perkembangan dunia usaha pada umumnya. Kehadiran industri asuransi pada umumnya merupakan hal yang rasional dan tidak terelakkan. Dalam menjalankan bisnis Asuransi Jiwa, perusahaan asuransi akan berkaitan dengan suatu permasalahan yang sangat dominan yaitu terdapatnya penurunan jumlah nasabah atau polis. Resiko kematian, kecelakaan atau cacat, dan kehilangan kemampuan untuk memperoleh penghasilan merupakan sebagian penyebab penurunan jumlah peserta asuransi. Penyebab penurunan ini disebut dengan decrement atau penyusutan. Berdasarkan modelnya terdapat dua model penyusutan yaitu model penyusutan tunggal dan model penyusutan majemuk (multiple decrement).

Penerapan model penyusutan majemuk, salah satunya dapat digunakan pada asuransi jiwa, yakni terdapat program asuransi yang menawarkan jaminan apabila terjadi kematian atau cacat dalam satu paket polis asuransi. Dalam pembentukan tabel penyusutan majemuk, dapat dikaitkan dari tabel penyusutan tunggal yang telah diketahui. Jumlah pembayaran premi untuk asuransi jiwa bergantung pada jenis program asuransi yang telah diambil. 
100 William Huda dkk.

\section{Asuransi Jiwa}

\subsection{Fungsi Bertahan Hidup (Survival Function)}

Misalkan $F_{x}(x)$ adalah fungsi distribusi dari peubah acak $X$, dengan $X$ adalah umur saat kematian yang didefinisikan sebagai berikut

$$
F_{x}(x)=\operatorname{Pr}(X \leq x)
$$

dan misalkan

$$
s(x)=1-F_{x}(x)=\operatorname{Pr}(X<x) .
$$

Untuk setiap $x$ positif, $s(x)$ adalah bayi yang baru lahir dapat bertahan hidup sampai $x$ tahun ke depan. Fungsi $s(x)$ tersebut disebut fungsi Bertahan Hidup.

\subsection{Peluang Hidup dan Peluang Mati}

Misalkan $T(x)$ adalah peubah acak yang menyatakan waktu sampai kematian dimana fungsi distribusi peluangnya adalah sebagai berikut

$$
{ }_{t} q_{x}=\operatorname{Pr}[T(x) \leq t], t \geq 0
$$

maka berlaku

$$
{ }_{t} p_{x}=1-{ }_{t} q_{x}=\operatorname{Pr}[T(x)>t], t \geq 0,
$$

dengan ${ }_{t} q_{x}$ adalah peluang seseorang berumur $x$ tahun akan meninggal dalam jangka waktu $t$ tahun dan ${ }_{t} p_{x}$ adalah peluang seseorang berumur $x$ tahun akan hidup $t$ tahun lagi atau mencapai usia $x+t$ tahun [1].

Misalkan $l_{x}$ adalah jumlah orang yang hidup pada usia $x$, maka peluang seseorang berumur $x$ tahun mencapai usia $x+t$ tahun adalah

$$
{ }_{t} p_{x}=\frac{l_{x+t}}{l_{x}}
$$

dan peluang seseorang berumur $x$ tahun meninggal dalam jangka waktu $t$ tahun adalah

$$
{ }_{t} q_{x}=1-{ }_{t} p_{x}=1-\frac{l_{x+t}}{l_{x}}=\frac{l_{x}-l_{x+t}}{l_{x}} .
$$

\subsection{Anuitas}

Anuitas adalah suatu pembayaran dalam jumlah tertentu, yang dilakukan pada selang waktu dan lama tertentu secara berkelanjutan [4]. Untuk menyederhanakan 
perhitungan, berikut simbol komutasi yang akan digunakan adalah:

$$
\begin{aligned}
D_{x} & =v^{x} l_{x}, \\
v & =\frac{1}{1+i}=(1+i)^{-1}, \\
N_{x} & =\sum_{i=0}^{w} D_{x+i}=D_{x}+D_{x+1}+D_{x+2}+\cdots+D_{w}, \\
S_{x} & =\sum_{i=0}^{w} N_{x+i}=N_{x}+N_{x+1}+N_{x+2}+\cdots+N_{w}, \\
C_{x} & =v^{x+1} d_{x}, \\
M_{x} & =\sum_{i=0}^{w} C_{x+i}=C_{x}+C_{x+1}+C_{x+2}+\cdots+C_{w}, \\
R_{x} & =\sum_{i=0}^{w} M_{x+i}=M_{x}+M_{x+1}+M_{x+2}+\cdots+M_{w} .
\end{aligned}
$$

Pembayaran nilai tunai anuitas awal seseorang kepada perusahaan asuransi digunakan perumusan sebagai berikut:

(a) Nilai tunai anuitas awal seumur hidup bagi seorang berusia $x$ tahun sebesar 1 satuan setiap tahun adalah

$$
\ddot{a}_{x}=\frac{N_{x}}{D_{x}} .
$$

(b) Nilai tunai anuitas awal berjangka bagi seorang berusia $x$ tahun, pembayaran paling lama $n$ tahun adalah

$$
\ddot{a}_{\overline{x: n \mid} \mid}=\frac{N_{x}-N_{x+n}}{D_{x}} .
$$

Sedangkan pembayaran besar santunan yang harus dibayarkan perusahaan asuransi kepada ahli waris digunakan perumusan:

(a) Premi tunggal bersih asuransi seumur hidup yang memberikan santunan kepada ahli waris pada akhir tahun kematian tertanggung adalah

$$
A_{x}=\frac{M_{x}}{D_{x}}
$$

(b) Premi tunggal bersih asuransi berjangka yang memberikan santunan kepada ahli waris apabila tertanggung meninggal sebelum berumur $x+n$ tahun adalah

$$
A_{\bar{x}: n \mid}^{\prime}=\frac{M_{x}-M_{x+n}}{D_{x}} \text {. }
$$

\section{Model Penyusutan majemuk}

Model penyusutan majemuk adalah model penyusutan jumlah polis dimana penyusutan tidak hanya disebabkan oleh satu sebab saja, misalkan kematian, namun mungkin juga disebabkan oleh cacat maupun sebab-sebab yang lain. 


\subsection{Peluang Penyusutan}

Beberapa simbol yang digunakan yang berhubungan dengan model penyusutan majemuk pada perhitungan asuransi jiwa adalah:

(i) $l_{x}^{(T)}$ adalah jumlah polis yang hidup pada usia $x$ tahun dan akan mengalami penyusutan yang diakibatkan oleh $m$ sebab, yaitu penyusutan ke-1, ke-2, $\cdots$, ke- $m$.

(ii) $d_{x}^{(k)}$ adalah jumlah polis yang mengalami penyusutan antara usia $x$ dan $x+1$, yang diakibatkan oleh sebab penyusutan ke- $k$.

(iii) $d_{x}^{(T)}$ adalah jumlah polis yang mengalami penyusutan antara usia $x$ dan $x+$ 1 yang diakibatkan oleh sebab penyusutan ke-1, sebab penyusutan ke-2, $\cdots$, maupun sebab penyusutan ke-m.

$$
d_{x}^{(T)}=\sum_{k=1}^{m} d_{x}^{(k)},
$$

dan

$$
l_{x}^{(T)}-d_{x}^{(T)}=d_{x+1}^{(T)} .
$$

(iv) $q_{x}^{(k)}$ adalah peluang seseorang berusia $x$ akan meninggalkan (keluar) dari kumpulan orang-orang berusia $x$ dalam 1 tahun, diakibatkan oleh sebab penyusutan ke- $k$.

$$
q_{x}(k)=\frac{d_{x}^{(k)}}{l_{x}^{(T)}} .
$$

(v) $q_{x}^{(T)}$ adalah peluang seseorang berusia $x$ akan meninggalkan (keluar) dari kumpulan dalam satu tahun, yang terlepas dari sebab penyusutan

$$
q_{x}^{(T)}=\frac{d_{x}^{(T)}}{l_{x}^{(T)}}=\sum_{k=1}^{m} q_{x}^{(k)} .
$$

(vi) $p_{x}^{(T)}$ adalah peluang seseorang berusia $\mathrm{x}$ akan tetap berada didalam kumpulan orang-orang berusia $\mathrm{x}$ paling sedikit satu tahun.

$$
p_{x}^{(T)}=1-q_{x}^{(T)}=\frac{l_{x+1}^{(T)}}{l_{x}^{(T)}} .
$$

Dengan cara yang sama diperoleh persamaan untuk ${ }_{n} p_{x}^{(T)}$ dan ${ }_{n} q_{x}^{(T)}$ adalah sebagai berikut

$$
{ }_{n} p_{x}^{(T)}=\frac{l_{x+n}^{(T)}}{l_{x}^{(T)}},
$$

dan

$$
{ }_{n} q_{x}^{(T)}=\frac{d_{x}^{(T)}}{l_{x}^{(T)}} .
$$




\subsection{Pembentukan Tabel Penyusutan}

Model penyusutan tunggal adalah suatu model penyusutan atau penurunan yang disebabkan oleh satu faktor saja. Tabel penyusutan majemuk dapat dibentuk apabila diketahui tabel penyusutan tunggal, yaitu dapat dirumuskan dengan

$$
\mu_{x}^{(T)}=\sum_{k=1}^{m} \mu_{x}^{(k)}
$$

Rumusan $q_{x}^{(k)}$ dapat dinyatakan sebagai berikut :

$$
q_{x}^{(k)}=\int_{0}^{1}{ }_{t} p_{x}{ }^{(T)} \mu_{x+t}^{(k)} d t
$$

Berdasarkan persamaan di atas, dapat diketahui untuk sebab penyusutan ke-1 menjadi

$$
\begin{aligned}
q_{x}^{(1)} & =\int_{0}^{1}{ }_{t} p_{x}{ }^{(T)} \mu_{x+t}^{(1)} d t=\int_{0}^{1} \frac{{ }_{t} p_{x}{ }^{(T)}{ }_{t}{ }^{(1)}{ }_{t}{ }{ }_{x}{ }^{(1)} \mu_{x+t}^{(1)} d t}{} \\
& \approx q_{x}^{\prime}(1) \int_{0}^{1} \frac{{ }_{t} p_{x}{ }_{t}{ }_{t} p_{x}(1)}{(1)} d t=q_{x}{ }^{\prime}(1) \int_{0}^{1}{ }_{t} p_{x}{ }^{(2)}{ }_{t} p_{x}{ }^{(3)} \ldots{ }_{t} p_{x}{ }^{(m)} d t .
\end{aligned}
$$

Dengan mengasumsikan penyusutan pada tabel penyusutan tunggal dalam satu tahun mempunyai distribusi seragam (uniform distribution of decrements) dan dengan menggunakan formulasi

$$
{ }_{t} q_{x}^{(k)}=t q_{x}^{(k)}
$$

maka diperoleh

$$
\begin{aligned}
q_{x}^{(1)} & \approx q_{x}^{\prime(1)} \int_{0}^{1}{ }_{t} p_{x}{ }^{(2)}{ }_{t} p_{x}{ }^{(3)} \cdots{ }_{t} p_{x}{ }^{(m)} d t \\
& =q_{x}^{\prime(1)} \int_{0}^{1}\left[1-{ }_{t} q_{r}{ }^{(2)}\right]\left[1-{ }_{t} q_{r}{ }^{(3)}\right] \cdots\left[1-{ }_{t} q_{r}{ }^{(m)}\right] d t \\
& \approx q_{x}^{(1)}\left[1-\frac{1}{2} \sum_{k \neq 1} q_{x}^{(k)}+\frac{1}{3} \sum_{k \neq 1} \sum_{l>k} q_{x}^{(k)} q_{x}^{(1)}-\cdots\right] .
\end{aligned}
$$

Untuk 2 (dua) sebab penyusutan, maka diperoleh

$$
q_{x}^{(1)}=q_{x}^{(1)}\left[1-\frac{1}{2} q_{x}^{(2)}\right]
$$

dan

$$
q_{x}^{(2)}=q_{x}{ }^{(2)}\left[1-\frac{1}{2} q_{x}^{(1)}\right]
$$


104 William Huda dkk.

\subsection{Model Penyusutan majemuk pada Asuransi Jiwa}

Untuk menyederhanakan perhitungan, diperlukan simbol komutasi atau simbol perantara sebagai berikut:

$$
\begin{aligned}
D_{x}^{(T)} & =v^{x} l_{x}^{(T)}, \\
N_{x}^{(T)} & =\sum_{t=0}^{\infty} D_{x+t}^{(T)}, \\
C_{x}^{(k)} & =v^{(x+1)} d_{x}^{(k)}, \\
M_{x} & =\sum_{t=0}^{\infty} C_{x+t}^{(k)} .
\end{aligned}
$$

Dalam asuransi jiwa pembayaran premi biasanya dilakukan secara berkala yang dinamakan anuitas. Anuitas pada penyusutan majemuk dapat didefinisikan sebagai berikut

(a) Nilai tunai anuitas awal seumur hidup bagi seorang berusia $x$ tahun sebesar 1 satuan setiap tahun adalah

$$
\ddot{a}_{x}^{(T)}=\frac{N_{x}^{(T)}}{D_{x}^{(T)}} .
$$

(b) Nilai tunai anuitas awal berjangka bagi seorang berusia $x$ tahun dengan pembayaran paling lama $n$ tahun adalah:

$$
\ddot{a}_{\bar{x}: n \mid}^{(T)}=\frac{N_{x}^{(T)}-N_{x+n}^{(T)}}{D_{x}^{(T)}} .
$$

Untuk membayar berapa besar santunan yang harus dibayarkan perusahaan asuransi kepada ahli waris digunakan perumusan sebagai berikut:

(a) Asuransi seumur hidup pada model penyusutan majemuk dinotasikan dengan $a_{x}^{(k)}$, adalah asuransi seumur hidup sebesar Rp.1,- untuk seseorang berusia $x$, yang berarti bila $x$ meninggalkan kumpulan dikarenakan penyusutan ke- $k$ maka ahli warisnya akan menerima pembayaran sebesar Rp.1,- pada akhir tahun $x$ meninggalkan kumpulan. Perhitungan $a_{x}^{(k)}$ adalah sebagai berikut:

$$
a_{x}^{(k)}=\frac{M_{x}^{(k)}}{D_{x}^{(T)}} .
$$

(b) Asuransi berjangka ( $n$ tahun) pada model penyusutan majemuk yang dinotasikan dengan $A_{\frac{\prime}{x: n} \mid}^{(k)}$ adalah asuransi yang memberikan santunan kepada ahli waris apabila orang yang diasuransikan mengalami penyusutan ke- $k$ dalam jangka waktu yang ditentukan. Namun apabila sampai jangka waktu asuransi, tertanggung tidak mengalami penyusutan ke- $k$, maka tidak ada pembayaran. Perhitungan adalah sebagai berikut:

$$
A^{\prime(k)}=\frac{M_{x}^{(k)}-M_{x+n}^{(k)}}{D_{x}^{(T)}} .
$$




\section{Contoh Aplikasi}

Seorang pemuda berusia 35 tahun hendak mengikuti program asuransi yang menawarkan santunan-santunan sebagai berikut.

(1) Apabila terjadi kematian, maka ahli waris akan mendapatkan santunan sebesar Rp.100.000.000,00.

(2) Apabila mengalami cacat, maka tertanggung mendapat santunan sebesar Rp.95.000.000,00.

Pembayaran premi dilakukan 10 kali pada setiap permulaan tahun. Perusahaan memberikan alternatif program asuransi dengan menawarkan bunga 6 persen per tahun:

(1) Asuransi seumur hidup

(2) Asuransi berjangka 25 tahun

Oleh karena itu, besar premi bersih dari ke-2 alternatif program asuransi tersebut dapat dihitung sebagai berikut:

1. Besarnya pembayaran premi jika mengikuti program asuransi seumur hidup dapat dihitung dengan cara sebagai berikut :

(1) Misalkan besarnya pembayaran premi atau besar pembayaran cicilan tiap tahun adalah B rupiah dan dibayarkan selama 10 kali pada setiap permulaan tahun. Dengan demikian didapatkan persamaan:

$$
\begin{aligned}
B \ddot{a}_{35: 10}^{(T)} & =100 \times 10^{6} A_{35}^{(d e)}+95 \times 10^{6} A_{35}^{(d s)} \\
\Leftrightarrow B\left[\frac{N_{35}^{(T)}-N_{45}^{(T)}}{D_{35}^{(T)}}\right] & =\left[100 \times 10^{6} \frac{M_{35}^{(d e)}}{D_{35}^{(T)}}\right]+\left[95 \times 10^{6} \frac{M_{35}^{(d s)}}{D_{35}^{(T)}}\right] \\
\Leftrightarrow B & =\left(\left[100 \times 10^{6} \frac{M_{35}^{(d e)}}{D_{35}^{(T)}}\right]+\left[95 \times 10^{6} \frac{M_{35}^{(d s)}}{D_{35}^{(T)}}\right]\right)\left[\frac{D_{35}^{(T)}}{N_{35}^{(T)}-N_{45}^{(T)}}\right]
\end{aligned}
$$

Nilai komutasi yang digunakan adalah nilai komutasi yang terdapat pada tabel penyusutan ganda pada lampiran yang dibentuk dari penggabungan tabel 1952 US Disability Benefit 5, Age Nearest dengan tabel 1941 US CSO Basic, Age Nearest, Male and Female. Dari nilai komutasi tersebut diperoleh

$$
\begin{aligned}
B & =\left(\left[100 \times 10^{6} \cdot \frac{1880,28}{11666,56}\right]+\left[95 \times 10^{6} \cdot \frac{573,57}{11666,56}\right]\right)+\left[\frac{11666,56}{165211,66-76098,76}\right] \\
\Leftrightarrow B & =2721459,519 \approx 2721460 .
\end{aligned}
$$

Jadi, dengan membayar sebesar Rp. 2.721.460,00. tiap awal tahun selama sepuluh tahun, pemuda tersebut dapat mengikuti program asuransi seumur hidup dan apabila terjadi kematian atau cacat, santunan akan diberikan kepada ahli waris pada akhir tahun kejadian.

2. Besarnya pembayaran premi jika mengikuti program asuransi berjangka 25 tahun dapat dihitung dengan cara sebagai berikut. 
(1) Misalkan besarnya pembayaran premi atau besar pembayaran cicilan tiap tahun adalah B rupiah dan dibayarkan selama 10 kali pada setiap permulaan tahun. Dengan demikian didapatkan persamaan:

$$
\begin{aligned}
& B \ddot{a} \frac{(T)}{35: 10 \mid}=100 \times 10^{6} A_{35: 25}^{r(d e)}+95 \times 10^{6} A_{35: 25}^{r(d s)} \\
\Leftrightarrow & B\left[\frac{N_{35}^{(T)}-N_{06}^{(T)}}{D_{35}^{(T)}}\right]=\left[100 \times 10^{6} \frac{M_{35}^{(d e)}-M_{60}^{(d e)}}{D_{35}^{(T)}}\right]+\left[95 \times 10^{6} \frac{M_{35}^{(d s)}-M_{60}^{(d s)}}{D_{35}^{(T)}}\right] \\
\Leftrightarrow & B=\left[100 \times 10^{6} \frac{M_{35}^{(d e)}-M_{60}^{(d e)}}{D_{35}^{(T)}}\right]+\left[95 \times 10^{6} \frac{M_{35}^{(d s)}-M_{60}^{(d s)}}{D_{35}^{(T)}}\right]\left[\frac{D_{35}^{(T)}}{N_{35}^{(T)}-N_{60}^{(T)}}\right] \\
\Leftrightarrow & B=\left(\left[100 \times 10^{6} \cdot \frac{1880,28-837,39}{11666,56}\right]+\left[95 \times 10^{6} \cdot \frac{573,57-163,05}{11666,56}\right]\right)+\left[\frac{11666,56}{165211,66-17644,22}\right] \\
\Leftrightarrow & B=971002,8174 \approx 971003 .
\end{aligned}
$$

Jadi, dengan membayar sebesar Rp. 971.003,00. tiap awal tahun selama sepuluh tahun, pemuda tersebut dapat mengikuti program asuransi berjangka 25 tahun dan apabila terjadi kematian atau cacat dalam jangka waktu tersebut, santunan akan diberikan kepada ahli waris pada akhir tahun kejadian, namun apabila tidak terjadi kematian ataupun cacat, maka ahli waris tidak mendapatkan pembayaran apapun.

\section{Kesimpulan}

Model penyusutan majemuk adalah model penyusutan dimana penyusutan jumlah polis tidak hanya disebabkan oleh satu sebab saja. Pembentukan tabel penyusutan majemuk ini dilakukan dengan menggabungkan tabel penyusutan tunggal yang telah diketahui. Besar premi yang dibayarkan untuk asuransi jiwa dengan penyusutan majemuk bergantung pada program asuransi yang diambil. Pada asuransi seumur hidup untuk seseorang yang berusia $x$, apabila dia berhenti menjadi anggota dikarenakan penyusutan ke- $k$, maka ahli warisnya akan menerima pembayaran. Sedangkan pada asuransi berjangka $n$ tahun, apabila orang yang diasuransikan mengalami penyusutan ke- $k$ dalam jangka waktu yang ditentukan, maka ahli waris akan menerima pembayaran. Namun, apabila sampai jangka waktu asuransi tertanggung tidak mengalami penyusutan ke- $k$, maka tidak ada pembayaran.

\section{Ucapan Terima kasih}

Penulis mengucapkan terima kasih kepada Bapak Dodi Devianto, Bapak Yudiantri Asdi, Bapak Admi Nazra, Bapak Mahdhivan Syafwan, Ibu Riri Lestari, dan Ibu Hazmira Yozza yang telah memberikan masukan dan saran sehingga paper ini dapat diselesaikan dengan baik.

\section{Daftar Pustaka}

[1] Bowers, N.L., H.U. Gerber, D.A. Jones, dan C.J. Nesbitt. 1997. Actuarial Mathematics Second Edition. The Society of Actuaries, USA 
[2] Borowiak, S.D. 2005. Financial and Actuarial Statistics an Introduction. Marcell Dekker, New York

[3] Catarya, I. 1988. Buku Materi Pokok Asuransi II. Karunika, Universitas Terbuka, Jakarta

[4] Jones, H.E. 1999. Prinsip-prinsip Asuransi Jiwa, Kesehatan dan Anuitas. Edisi Kedua. FLMI Insuransce Education Program Life Management Institute Roma Atlanta, Georgia

[5] Jordan, C. W. 1991. Life Contingencies Second Edition. The Society of Actuaries, USA

[6] Salim, A. 2007. Asuransi dan Manajemen Risiko. Raja Grafindo Persada, Jakarta

[7] Sitanggang, C., D. Kerami. 2003. Kamus Matematika. Balai Pustaka, Jakarta

[8] Takashi, F. 1992. Matematika Asuransi Jiwa Bagian I. Incoporated Foundation OLICD Center, Tokyo 